Acta Universitatis Wratislaviensis No 4087

Anglica Wratislaviensia LIX, Wrocław 2021

https://doi.org/10.19195/0301-7966.59.2

\author{
Ali Shehzad Zaidi \\ ORCID: 0000-0001-6129-4485 \\ State University of New York at Canton \\ zaidia@canton.edu

\section{Water as a Divine Mirror in the Poetry of Daud Kamal}

\begin{abstract}
In the poetry of Daud Kamal, water figures as an image of mercy, as in the Quran, and as a mirror that reflects a divine hidden presence. The rock pool evokes the memory of Gandhara and other foundational civilizations born in love and creative ferment. Conversely, the images of drought, heat, and dust symbolize a parched spiritual order. The river, a recurring archetypal image in Kamal's poetry, represents the fluid self that is subsumed into collective identity to become a poetic distillate of history.
\end{abstract}

Keywords: Daud Kamal, water imagery, drought imagery, Pakistani poetry in English, Gandhara civilization, Islamic poetry

Drawing upon various spiritual traditions of the Indian subcontinent, Daud Kamal (1935-1987) expresses the divine presence through syncretic water imagery that evokes a legacy of divine love. The ideas of mercy and water that are intertwined in the Quran (Lings 67) are also closely related in Kamal's poetry. Kamal uses the metaphors of the boat and river to convey the soul's pilgrimage through time. Through a language of water, Kamal, like his Sufi predecessors, transverses many cultures, reviving the nearly forgotten heritage of the Gandhara civilization that thrived in the region of what is now northern Pakistan and eastern Afghanistan.

At the center of this civilization was Peshawar, the winter capital of Gandhara that was then known by its ancient name of Purushpura. The place name "Gandhara" had two possible meanings, the first being "fragrant lands"- from the words Qand/Gand ("fragrance") and Har (lands) — while the second is Qand/Gand, from the word Kun which means "well" or "pool" (Naveed). The images of incense and a rock-pool evoke both meanings in this excerpt from "Pilgrimage": 
Embraced by his own separateness he hears a voice

searching for him. The forest opens

into a clearing and the smell of incense

lingers on in the ruined temple. A group

of peasants descend the stone steps

with deliberate calm.

Sacred fish

in a rock-pool

Old mirror webbed with cracks.

(Before the Carnations Wither 8)

Incense was used to mark the passage of time in ancient China. An ancestral voice draws the impersonal subject of this poem into another time and into a ruined temple with stone steps that represent spiritual ascension. The descent of the peasants on the steps represents their withdrawal from a sacred dimension of existence. Stone embodies the image of a lasting reality (Baring and Cashford 96). The rockpool images a place where life, ideas, and cultures gestate, as in the Peshawar Valley, ringed by the Karakoram and Hindu Kush mountains. The "old mirror webbed with cracks" reflects a divine love that has undergone occultation in our time.

This hidden yet discernible aspect of the sacred also defines "Prayer-Beads":

Under

the shade

of a willow tree

where the river bends

in a rock-pool

prayer-beads rise

to the surface

from the mouth

of an invisible

fish.

(Before the Carnations Wither 9)

The willow tree is sacred to the moon and is related to rivers and endurance (de Vries 500). "Prayer-Beads" conveys a hierophany, namely that sacrality inheres in all forms of life and in the universe itself.

As in "Prayer-Beads," Kamal hints at surreptitious spirituality under oppressive orthodoxy in "Water-Carrier," which conveys a devotion akin to that of the saints and poets who won converts to Islam through love and living example. The poem's subject is dressed in rags, carrying a goatskin to deliver water:

Like all the rest

he waits his turn

at the municipal tap.

Killing time,

he tears off with his teeth

the skin of a sugarcane. 
His bare feet know the backstreets

intimately - the way he knows

his straw mat after dark.

Twice a day delivering water

at the nearby mosque

and not a single prayer.

(A Remote Beginning 31)

The final line of the poem undermines itself, for water delivery is a form of prayer. The tearing of the sugar cane skin adumbrates hidden sweetness and deep spiritual experience. The water carrier's feel for the backstreets and his straw mat evince a sense of place and secret access to an oneiric world inaccessible through the front entrance, that is to say, through orthodox institutional practices and performative, gestural religiosity. The water carrier who provides hidden sustenance to a mosque without outward manifestations of devotion projects Kamal's own relation to Islam and memorializes the Prophet Mohammed's family who were massacred at Kerbala in $680 \mathrm{AD}$ after being deprived of water.

In "A Ruined Monastery", water imagery conveys the camouflage and persistence of the sacred in the forms and rituals of everyday life:

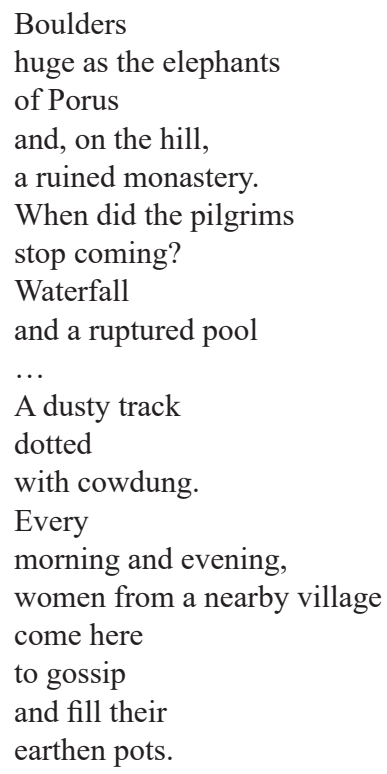

(Before the Carnations Wither 15)

Cows are sacred animals in Hinduism and Buddhism. The cow dung on the dusty track represents a residual trace of these repressed religions. The women who gather water undermine the premise in the question "When did the pilgrims stop coming?", for they are pilgrims in disguise. The tall and majestic Porus ruled over a land between the Jhelum and Chenab rivers in the Punjab. His army of chariots and elephants was defeated by Alexander the Great's swift cavalry in 326 BC. 
Upon being captured, a wounded Porus was asked by Alexander how he wished to be treated. Porus replied, "As befits a king", upon which Alexander granted him the right to rule over his domains (Keay 72-73). The massive boulders exemplify rock, which, in the words of J. E. Cirlot, symbolizes permanence and integrity, and whose cohesion gives it mystic significance (274). Moreover, they reveal the survival of ancient rituals in the forms of everyday life - in this case, the villagers who trek to the ruined monastery for water.

During the Golden Age of Mahayana Buddhism (60-230 AD), kindness and concern for humanity became preeminent. Mahayana Buddhism was more inclusive than the austere, monastic Theraveda Buddhism, which was the other major branch of Buddhism (Armstrong 378). Under the aegis of the Kushan dynasty, over a thousand monasteries in the Taxila, Swat, and Peshawar Valley regions provided cultural and spiritual support to Gandharans (Samad 21, 99). Early Buddhist shrines had the shape of an egg or womb with an open aspect meant to invite pilgrim rituals (Smart 279-80). In the second century AD, the sacred texts of Mahayana Buddhism spread throughout Asia after Buddhist monks began translating them into Chinese. The Prophet Muhammad famously exhorted his followers to go to China in search of knowledge (Al-Suhrawardy 79), or, in other words, to learn from non-Islamic spiritual traditions.

The Muslim invaders of the Indian subcontinent failed to heed his words. In the late twelfth century AD, the armies of Qutb-ud-din Aybak (1150-1210), founder of the Mamluk dynasty of the Delhi Sultanate, conquered the plains of the upper Ganges. One of Aybak's generals, Muhammad Bakhtiar, destroyed the Great Monastery of Nalanda, then the greatest center of learning in Asia, and murdered its inhabitants because the monastery's libraries did not have a copy of the Quran. Bakhtiar then destroyed the two remaining Great Monasteries at Somapura and Jagadalala (Allen 2-5).

The memory of such atrocities pervades "Crow", in which injustice is a historical constant. Here the monsoon rains are an instrument of time, a cosmic force that renews even as it destroys:

The crow

sharpens his beak

on a shrapnel bone.

He has tunnelled

through the black entrail

of innumerable nights

and smeared his shadow

on the saffron fields

of Kashmir.

Centuries ago,

he tore the flesh

of a Shudra girl

raped and murdered

by a Brahmin priest. 


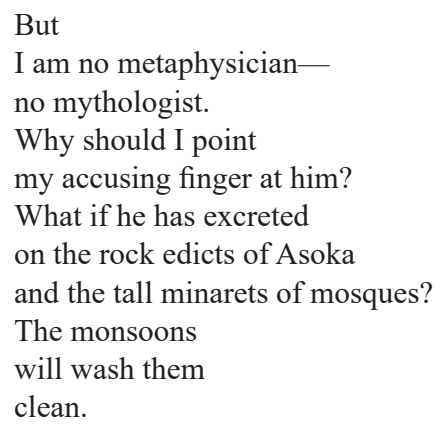

(Recognitions 6)

The image of the crow is at once destructive and restorative (Archive 248), for these disquieting emissaries of death, like the monsoons, wipe the slate clean. The image of saffron recalls the color of the robes of Buddhist monks and therefore evokes the sacred. Saffron also evokes joy. In Urdu, there is an idiomatic expression addressed to someone who appears strangely euphoric: "Did you just pass through a saffron field?"

Kamal alludes to Asoka, the ruler who governed India through moral persuasion and compassion around 2,250 years ago. Asoka's rock edicts, fourteen of which survive throughout the Indian subcontinent, were India's first written script. The precepts contained therein abrogate the Brahmin caste system, protect living beings from slaughter or sacrifice, mandate medical care for both humans and animals and enjoin respect for parents and generosity to friends and family. The edicts address posterity: the fifth edict states that it had "been written on stone so that it might endure long and that my descendants might act in conformity with it" (Allen xi-xv, 406-409). Those descendants include the citizens of modern Pakistan, a country that has devolved into a kleptocracy where public school textbooks glorify conquerors and soldiers.

Through the medium of water, Kamal mourns the betrayal of the ethos of Gandhara, speaking for those whose voices have been stifled in the "the dumb throat of history" ("The day brightens slowly", Before the Carnations Wither 18). "Ancestral Breast Howl" opens with a man sewn up alive and hurled into a river from the ramparts of a fort:

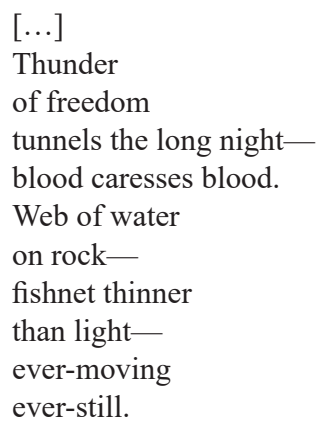


The paradoxical final lines ("ever-moving / ever-still") evoke the violent truncation of ancestral memory, which, though silenced, continues to reverberate through the pain of descendants whose "blood caresses blood".

Kamal's Rajput ancestry adds poignancy to this poem. In 1568, a Mughal army massacred more than twenty-five thousand Rajputs after the conquest of Chittorgarh Fort during Mughal emperor Aurangzeb's brutal forty-nine-year reign (1658-1707). As a prince, Aurangzeb subjugated two Deccan sultanates ruled by Shia rulers who were patrons of the arts, and where Muslims and Hindu subjects co-existed peacefully in shared state governance. In pursuit of the Mughal throne, Auranzeb murdered his three brothers, including Prince Dara Shikoh, the rightful heir. Dara was a poet who translated the Upanishads into Persian, and who believed the spiritual essences of Hinduism and Islam to be compatible. Aurangzeb's treachery and military skill overcame Dara's brave Rajput warriors (Keay 338-41). In 1680, Aurangzeb sent his son Akbar to crush a Rajput revolt, but Akbar joined the revolt instead, only to be defeated. Aurangzeb destroyed thousands of temples and forcibly converted Hindus and Sikhs, putting to death approximately over four and half million people in the process. He banned music and ceased the patronage of scholars that had made the Mughal Empire a center of learning (White 233-35). Through violence, the Mughal empire grew rapidly under Auranzeb but began to disintegrate after his death.

Aurangzeb's cruel legacy endures. Fundamentalists, purporting to restore Islamic culture to its supposedly original state, have turned Pakistan into a Salafi-haunted nightmare. Thousands of Shias, Christians, Ahmedis, and Hindus have been murdered in recent years by extremist Sunni groups such as Sipah-e-Sahaba and Lashkar-e-Jhangvi. Spiritual dislocation, insecurity, and loss of cultural identity continue to feed the fears, anxieties, and meanness that spur the Taliban to demolish the Bamiyan statues in Afghanistan, the Daesh to destroy the ancient cities of Palmyra in Syria and Nimrud in Iraq, and Saudi monarchs to level shrines and historic sites.

Kamal's hitherto unpublished "Sentinel"1 opens with an epigraph from Alexander Gladkov: "Poet, keep watch, keep watch, / You must not all asleep—/ You are eternity's hostage / In captivity to time". "Sentinel" leaps from the distant past to the present without transition or explanation, forcing the reader to engage history more deeply:

Within the besieged fortress

all the women jumped into the well

to save their honour.

But this happened centuries ago

and their screams live now

only in myths and history.

A bomb explodes in a cheap restaurant-

1 The poem "Sentinel" has never been published before. Daud Kamal included it in a manuscript of his poems that he gave to Ali Shehzad Zaidi (Editor's note). 
men have suddenly lost

Their appetite for living.

The entire city is burning-

priests have forgotten to pray

and the sky is too hot for vultures.

In his vigil over history, Kamal connects present-day terrorism to a centuries-old mass suicide. The women in the burning fort, who seek final refuge in water from Aurangzeb's soldiers, prefigure those trapped in the violence of our own times. The ellipsis in this poem transmits history's archetypal circularity and inaccessibility of meaning. History must repeat itself, for as Kamal observes in "Thirst", "History is a demented village-elder / to whom no one / pays any attention" (Rivermist 77). "Sentinel" exemplifies Kamal's insight that "all great literature is both in time and outside time" ("The Role of the Writer" 43).

Kamal's images related to heat, such as those in "Sentinel", evoke a desiccated spiritual order. In "Absence Down a Dark Path", the cruelty of zealots induces thirst: "Someone whispers: they stoned / A new-born infant to death. / I call my son: / bring me a glass of water" (Rivermist 104). Drought conveys a similar spiritual insufficiency in this excerpt from "Dragonflies":

[...] What

shall our children inherit?

Wine turning into

vinegar. Nothing

burns brighter than

dead grass.

(Before the Carnations Wither 102)

The conditions for violence, connoted through the image of dead grass, persist in a country whose educational system breeds ignorance, whose economic system immiserates the already poor, and whose military intelligence agency murders activists with impunity.

In "The Sky's Empty Paths", water, void of divine light, has become a force that smothers and suffocates. The theme of the destruction of wisdom and spirituality underlies this poem, in which a ruined monastery occupies a spatial and temporal background:

Gunshots rend the air and a sandgrouse paints the dew-bright morning stones with blood. Consummate artist.

In the background the ruins of an ancient Buddhist monastery.

Now and then rich Japanese tourists come in busloads, taking photographs.

Demolished moon, the curved icicle of a trigger. 
This is the season of hunting.

Visions of fern leaves

and rock-pools are irrelevant here.

The world we live in

is cruel and corrupt.

A dark sea closes in on us.

(Before the Carnations Wither 43)

The moon, which represents cosmic memory (Nasr 114), has degraded in this poem into the image of the curved icicle of a trigger - the chill touch of death. Like the images of water and the moon, art itself has become grotesque: a sandgrouse, shot by hunters, paints the stone with its spilled blood. A murderous sea corrodes that which ought to endure, to which the monastery ruins stand in mute testimony. Gone are the visions of the fern leaf, a symbol of sincerity and endurance that inspires reveries and prophecy (de Vries 180), and of the rock pool that retains water, the source of life and symbol of embryonic civilization.

The image of the rock pool evokes the gestation of civilization founded in love in Kamal's "An Arch of Stars":

Hope is a torn banner,

barely visible

through all this travelling dust.

But should luck lead you

To the pool,

You'll find an arch of stars,

Those bare simplicities:

her eyes, two hands that

meet beneath the water's chill.

(Before the Carnations Wither 56)

The arch represents initiation into a higher spiritual state, and its stars convey a sense of divine light as well as distant ideals and possibilities (Cooper 14; de Vries 440). Water is a mirror, and the image of the eyes in the pool conveys the insight of Paul Claudel that "water is the gaze of the earth, its instrument for looking at time" (qtd. in Bachelard 31).

The cosmic love energy of the pool reappears in veiled guise in this excerpt from "He and She":

Though they are not animals

nor is their room a cage,

they think they can

drown their fears

in the hot liquidities

of love.

Hallucination of white gold

on distant mountains-

the savage drumming of rain 
on tin-roofs.

Lightning rips the night

over and over again.

Lanes turn into muddy torrents.

Her beauty has burnt his eyes

but he imagines

he sees her still

as a silver hulk

in the folds of an impossible sea.

There is no moon

but they will never forget this night.

Nothing

will tear him

from her now-

not even the fish-hooks in his flesh

which the black tide pulls.

Ruminant walls muffle

their moans.

(Before the Carnations Wither 21)

In the tradition of Sufi poetry, "He and She" eroticizes the divine. The "liquidities of love" recreate the image of the pool, which is framed first by "ruminant walls" and then by the rock of "distant mountains" with their "hallucination of white gold". The backgrounds of the gilded images in Buddhist iconography were meant to reflect divine light; gold was called "mineral light" in India (Chevalier and Gheerbrant 439). The image of gold in this poem sensualizes the memory of Gandhara with its traditions of learning and religious pluralism.

The "silver hulk" in "He and She" evokes the moon boat, a common trope in Islamic and Asian poetry that traces a spiritual journey. This archetypal image, like that of the beloved as a lost garden, can be found in the qasida or ode from pre-Islamic Arabic times (Sells 90). The boat journey marks the end of a dark, cyclical existence in "Estuary": "The swallow make loops / in the air—/ vanishing black necklaces ... The silted hulk / of a wrecked boat" (Before the Carnations Wither 82). The vanishing black necklaces trace a soul freed from the hangman's noose of everyday existence. Swallows metaphorically connote spiritual awakening and freedom, for they anticipate the end of a journey as sailors approach a port or island.

In "Passing Through", water imagery suggests imminent mercy or deliverance, much as it does in the Quran:

Cloudy autumn sky-

a gust of chilly wind

threatening rain.

...The streets are full.

Only the birdcage

hanging from the branch

of a fig-tree 
is empty. Under it

a bearded scribe

(Solomon come back to life)

dips his pen into an inkwell

and with a flourish

begins a letter

for a woman

whose back is turned toward me.

(Rivermist 86)

Kamal only provides a bare outline of a story, leaving us to envision the many possibilities therein. Who is passing through in this poem? Is it the scribe who, moving from village to village to ply his trade, is glimpsed as he writes for the woman? Is it the woman with the hidden face that represents her denied or incipient personhood? Is it the poet persona who observes the street scene, perhaps from a car or train window? Do the readers pass through this poem as they imagine what brought the scribe and the woman together? Does Kamal pass through the minds of his readers as a spectral presence to revisit the scene? Or does the divine presence transfigure this scene as it passes through? For the woman's unseen face hints at the veiled presence of the Beloved.

Two Quranic allusions situate "Passing Through" within the tradition of Islamic mystical poetry. First, a Solomonic scribe is writing a letter under a fig-tree, from which hangs an empty cage. The Surah titled The Ants relates that Solomon could speak the language of birds (27: 15-16), whose migration might be understood metaphorically as souls in evolution. The empty birdcage suggests that the woman seated before the scribe has just escaped bondage. Second, the fig-tree (from which the birdcage hangs) recalls the Surah The Fig, which promises reward for those who do righteous deeds. This image, which also recalls the Bodhi Tree, the fig-tree under which the Buddha achieved enlightenment, conveys the continuity and interrelation of the religions of the Indian subcontinent. In an interview, Kamal said that he wanted his poetry "to move towards greater introspection, allusiveness, compression at the deeper level [and] suggest a sense of awe, mystery, and something strange" ("Interview" The Nation iv). "Passing Through" achieves all this while affirming the emancipatory and sacred nature of the act of writing.

In "Exile", water, taking the form of tea, preserves memory. In this poem, the exile, cast adrift as the last of his kind, experiences the chronologies of past and future as the topographies of motherland and exile:

They call him mad but he's the only one

to understand

the trees and beasts

in his old Bokhara rug.

There, in the midst

of everything, 


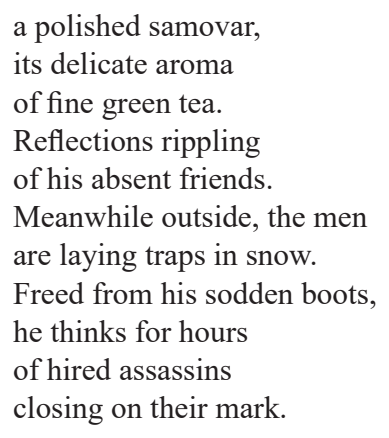

(Before the Carnations Wither 68)

This poem expresses a sense of entrapment in a disjunctive modernity. In a dynamic interaction with the past, reflections of friends ripple in the sea in which they are submerged. The hired assassins represent cultural erasure at its crudest; namely, the murder of those who embody memory and dignity. They also hint at the destructive effect of capitalism on culture. As the assassins close in, the exile recreates the aura of another age with the ceremony of tea. Weighed down with the waters of despair in his sodden boots, the exile still communes with friends and a lost world. His leisure and slow deliberation defy the lethal and relentless acceleration of modernity, at once a final act of affirmation and a premonition of death.

The creations in the rug in "Exile" are more than visions of beauty; they recount the stories and myths of a people that connect the exile to a living universe. The samovar in which the exile prepares his last tea returns us to a time in Persia, Russia, and Central Asia when artisans created objects that were at once useful, beautiful, and durable. The detail of the polished samovar shows how objects glow in the presence of remembrance and love. In his 1906 classic The Book of Tea, Okakura Kazuko describes the cult of tea that evolved from Zen ritual as "a worship of the Imperfect ... founded on the adoration of the beautiful" and as a "moral geometry [that] defines our sense of proportion to the universe" $(3-4,35)$.

An archetypal image in Kamal's poetry, the river, reflects our ever-changing selves, for as Gaston Bachelard observes, "[w]ater is truly the transitory element ... [a] being dedicated to water is a being in flux" (6). Kamal was drawn into the history and poetry of other ages. In his "Rain in the Moss", the river symbolizes this drift into collective memory: "I yearn for the river's broad sweep-its total embrace" (A Remote Beginning 41). The river imagery in the epigraph of Kamal's "Cleavage" (Before the Carnations Wither 37) is from Pablo Neruda's "The Heights of Macchu Picchu": "I wished to swim in the most ample lives, the widest estuaries" (179). The epigraph expresses the need to merge into other dimensions, into the spiritual and intellectual currents which preserve collective life.

Kamal exemplifies the kind of poet who, in the words of Bachelard, "discovers enduring water, unchanging, reborn, which stamps its image with an indelible mark and is an organ of the world, the nourishment of flowing phenomena, 
the vegetating and polishing element, the embodiment of tears" (11). Through the medium of water, Kamal engages in an extended love dialogue in which waves or ripples express the divine:

The future

curves on another shore.

Tongues of water

cradle our startled dreams.

Moss-grown stepping-stones.

The stars burn fiercely.

They tell us what we are.

(“Kingfisher" 171)

The image of the stars speaks to our paradoxical transience and immortality. The stepping-stones, which connote spiritual ascendance and endurance, are covered with moss, a symbol of growth and fertility.

We again see the image of the wet stones that draw us to our divine origin in this excerpt from "Anniversary":

Cascading back

to the source

over a difficult terrain

but the heart remembers.

Wet stones

conscious of their lineage -

the chopped-up moon

in paddy-fields.

(Before the Carnations Wither 93)

The image of the chopped-up moon has the power of invocation, for as Jacques Ellul tells us, "prayer holds together the shattered fragments of the creation" (177).

Water imagery expresses a state of peace and insight in "Occasionally a Beautiful Yellow Spotted Fish Appears...". Moving through temporal and spatial planes like a pilgrim in search of lost love, Kamal anchors his elegiac sense of dislocation in memories of Mughal civilization to find transhistorical meaning in the deepest recesses of his being:

Empty pavillions, no trace of imperial footprints

on the grass. And the garden, refreshed by rain,

rejoices, dying forever in a sunburnt land.

I'm half-asleep (the back of my shoulder

a convenient bookrest for my son)

and dreaming once more of you.

Far away are the cypresses, cascades,

ancient brick parterres and a remorseless moon.

Last night again you called to me

as though you were drowning and I saw you 
more vividly than Jehangir saw his poppy seed

go down to the bottom of the pool.

$[\ldots]$

\section{(Before the Carnations Wither 63)}

The poem's epigraph, taken from the memoirs of Mughal emperor Akbar, flows from the poem's title: " $\ldots$ and whenever this occurs, the year is reckoned a fortunate one. It appeared about this time, and caused great joy". Akbar took his plunge into enlightenment at Achebal, a rest place built by Nur Jehan, Akbar's daughterin-law and wife of prince Jehangir. Pupul Jayakar describes this exquisite serai on the road from Lahore to Srinagar:

For hundreds of years, pilgrims had come to this sacred site because of the healing properties of the spring water, though myths of the yakshis, water and tree spirits who guarded the spring, had long disappeared. Nur Jehan had built a walled garden around the spring, enclosing an area planted with chinar and poplar trees. At one point in the enclosed area the spring that gushed torrentially from the earth fell as a sheet of water to lower levels of the garden. The huge branches of the chinar trees spread across the falling waters. Below the fall were pools and fountains, and channels had been laid to carry the water to distant parts of the garden. The channels were so planned that the ray of the sun created rainbows as they caught the spray of waterfall and fountain. (214)

"The fountain in the center of the Islamic garden", Emma Clark explains, "represents the ever-flowing waters of the Spirit, constantly renewing the soul" (84). In this poem, Kamal speaks to the divine presence seen in water and dreams.

"Occasionally a Beautiful Yellow Spotted Fish Appears..." concludes in satori:

My son stirs in sleep. His comic book

plunges me down into the abyss. I'm wide awake.

No more, it seems, than a recurring nightmare-

all too familiar by now, not taken seriously.

The swallows go on dipping their wings

in the waterfall.

\section{(Before the Carnations Wither 64)}

These moments of peace with his son are a temporary respite from the clockwork of the daily grind. The comic book of his sleeping son mirrors the ongoing follies of humankind. The poet falls through various time planes of profane existence to arrive at a spiritual port of call symbolized by the swallows and their touch of water. This poem in particular exemplifies Northrop Frye's dictum that "if both poetry and religion are functioning properly, their interpenetration will take care of itself" (410).

In an interview, Kamal when asked how he made a poem, responded, "How do I then make a poem? The word 'make' is I think a bit too mechanical; it implies a carefully conscious process, even fabrication. Perhaps I am a clay vessel in a drought-stricken land waiting for rain. Or to change the metaphor, fishing by ob- 
stinate isles" ("Interview," Journal of the English Literary Club 72). The image of the clay water vessel connotes one who brings, in a spiritual sense, succor and relief to the people of Pakistan and beyond. In this capacity, Kamal enacts these lines of one of his favorite poets, Philip Larkin: "And I should raise in the east / A glass of water / Where any-angled light / Would congregate endlessly" ("Water" 91).

\section{References}

Allen, C. 2012. Ashoka: The Search for India's Lost Emperor. New York: Overlook Press.

Al-Suhrawardy, A. A. (ed.). 2001. The Wisdom of Muhammad. New York: Citadel Press.

Archive for Research in Archetypal Symbolism. 2010. The Book of Symbols. Reflections on Archetypal Symbols. Cologne: Taschen.

Armstrong, K. 2006. The Great Transformation: The Beginning of Our Religious Traditions. New York: Alfred K. Knopf.

Bachelard, G. 1983 [1942]. Water and Dreams: An Essay on the Imagination of Matter. Trans. Farrell, E. R. Dallas: Pegasus.

Baring, A. and J. Cashford. 1993. The Myth of the Goddess: Evolution of an Image. New York: Penguin.

Chevalier, J. and A. Gheerbrant. 1996. Dictionary of Symbols. Trans. Buchanan-Brown, J. London: Penguin Books.

Cirlot, J. E. 1971. A Dictionary of Symbols. Trans. Sage, J. London: Routledge and Kegan Paul.

Clark, E. 2011. "Underneath Which Rivers Flow.” In: Chittick, W. C. (ed.). The Inner Journey: Views from the Islamic Tradition. Sandpoint, Idaho: Morning Light Press, 82-87.

Cooper, J. C. 1978. An Illustrated Dictionary of Symbols. London: Thames and Hudson.

Ellul, J. 2012. Prayer and Modern Man. Trans. Hopkin, C. E. Eugene, Oregon: Wipf and Stock.

Frye, N. 2009. "Expanding Eyes.” In: O'Grady, J. and E. Kushner (eds.). The Critical Path and Other Writings on Critical Theory 1963-1975. Toronto: Toronto UP, 391-410.

Jayakar, P. 1986. J. Krishnamurti: A Biography. New Delhi: Penguin Books.

Kamal, D. 1974-1976. "The Role of the Writer." Journal of the English Literary Club. Department of English and Modern Languages, University of Peshawar. 43-45.

—. 1979. Recognitions. Budleigh Salterton: Interim Press.

- 1984-1985. Interview by Salim-ur-Rahman. Journal of the English Literary Club. Department of English and Modern Languages, University of Peshawar. 72-74.

—. 1985. A Remote Beginning. Budleigh Salterton: Interim Press.

-. 1987. Interview by Tariq Rahman. The Nation (Pakistan). 19 June. iv.

-. 1992. Rivermist. Islamabad: National Book Foundation.

- 1995. Before the Carnations Wither. Peshawar: Daud Kamal Trust.

—. 2006. "Kingfisher." The Grove: Working Papers on English Studies 13. 171.

Kazuko, O. 1956 (1906). The Book of Tea. Rutland, Vermont: Charles E. Tuttle.

Keay, J. 2000. India: A History. New York: Grove Press.

Larkin, P. 2004. "Water." Collected Poems. New York: Farrar, Straus and Giroux, 91.

Lings, M. 1991. Symbol and Archetype, A Study of the Meaning of Existence. Cambridge: Quinta Essential.

Nasr, S. H. 2007. "Traditional Cosmology and Modern Science." Interview by Philip and Carol Zaleski. In: Chittick, W. C. (ed.). The Inner Journey: Views from the Islamic Tradition. Sandpoint, Idaho: Morning Light Press, 104-120. 
Naveed, M. bin. “Gandhara Civilization.” Encyclopedia of World History. 7 July 2015. Web. 15 June 2017.

Neruda, Pablo. 1990. Pablo Neruda: A Bilingual Edition. Tarn, N. (ed.). Boston: Houghton Mifflin. The Quran. 2008. Trans. Khalidi, T. New York: Penguin.

Samad, R. 2011. The Grandeur of Gandhara. New York: Algora.

Sells, M. 1999. "Bewildered Tongue: The Semantics of Mystical Union in Islam.” In: Idel, M. and B. McGinn (eds.). Mystical Union in Judaism, Christianity and Islam. New York: Continuum, 87-124.

Smart, N. 1996. Dimensions of the Sacred: An Anatomy of the World's Beliefs. Berkeley: California UP.

White, M. 2012. Atrocities: The 100 Deadliest Episodes in Human History. New York: Norton.

Vries, A. de. Dictionary of Symbols and Imagery. London: North-Holland Publishing Co., 1974. 
Anglica Wratislaviensia LIX, 2021

(C) for this edition by CNS 